\title{
Striated muscles in visceral organs of vertebrates
}

\author{
Vladimir M Subbotin
}

Correspondence: vsubbotin@arrowheadpharma.com (OR) vladimir.m.subbotin@gmail.com

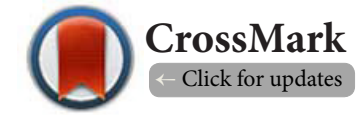

Director of Pathology, Arrowhead Pharmaceutical, Madison, Wisconsin 53711, USA.

\begin{abstract}
Pathologists involved in the examination of small rodent tissues are familiar with the presence of striated muscle in walls of intrapulmonary veins. Because these striated muscles express cardiomyocyte markers and are involved in rhythmical contraction during systole, this morphologic arrangement was named "pulmonary myocardium". Striated cardiac muscles of intrapulmonary veins have also been found in numerous species, including non-human primates. Great attention has been given to animal striated pulmonary veins because in humans, the presence of cardiomyocytes in the pulmonary veins (myocardial sleeves) is a major origin of paroxysmal atrial fibrillation. It is unequivocally suggested that direct extension/migration of cardiomyocytes from the left atrium into pulmonary veins is the origin of "pulmonary myocardium". This model sounds logical in regard to humans and large mammals because in these cases, striated myocytes extend into pulmonary veins only by $10-30 \mathrm{~mm}$ from the left atrium. However, the cardiomyocyte direct extension/migration model becomes less parsimonious when applied to the numerous small intrapulmonary veins with striated muscles in their walls in small mammals. In 1972, Alfred Sherwood Romer, renowned for his contributions to the study of vertebrate evolution, suggested that visceral smooth muscle cells developed a striated phenotype due to the need for more efficient musculature. Romer theorized that the primary anatomical division of the vertebrate muscular system should be not into smooth and striated types but into somatic and visceral systems, because the line of division along the gut between striated and smooth musculature is not a fixed point. Romer's work offered a parsimonious model for the presence of striated muscle in the walls of the intrapulmonary veins-visceral smooth muscle cells, which are capable of differentiating into striated muscle cells, are always present; whether they differentiate depends on functional demands. From Romer's hypothesis, it also could be foreseen that striated muscle could appear in visceral compartments other than the blood circulatory system and pharyngeal muscles to facilitate functional needs. Indeed, it was shown that 1) the lymphatic system of many low vertebrates acquired a lymphatic heart with striated muscle cells; 2) some vertebrates also acquire striated muscles in tunica Muscularis of the stomach and intestine. The facts above undoubtedly corroborate Prof. Romer's notion on the evolution of the vertebrate muscular system.
\end{abstract}

Keywords: Vertebrates, evolution, visceral organs, smooth muscles, striated muscles, intrapulmonary veins, lymphatic hearts, Alfred Sherwood Romer

\section{Correspondence}

The daily experience of any microscopic pathologist (anatomical, clinical, veterinarian, or toxicologic) contains unexpected morphologic findings. They can be pathologic findings in organs that ought to be normal as the organisms have not shown any signs of diseases. We categorize such findings as a "background or accidental" pathology [1]. Other unexpected findings include normal (or altered) structures in an unexpected location. These atypically located structures, termed "heterotopic", are usually results of genetic or developmental errors. The above two types of unexpected findings are rare (except in genetically modified animals), and we consider them "structural noise". However, there is a morphologic phenomenon of a third type, which is more perplexing than unexpected. It is the constant participation of cells/tissues in the formation of normal organs in situations when the participation of these particular cells is puzzling and contradicts common sense. I would like to elaborate on the above notions by providing 
the example of the permanent presence of striated muscles in visceral organs.

During my decades of experience in pathology, I have come countless times across the same routine finding: the presence of striated muscle fibers in lung sections. These striated lung muscles, also known as 'pulmonary myocardium, appear in a wall of pulmonary veins of rodents and many other species and are familiar to all morphologists, especially those involved in microscopic analysis of rodent tissues and toxicologic pathology (Figure 1).

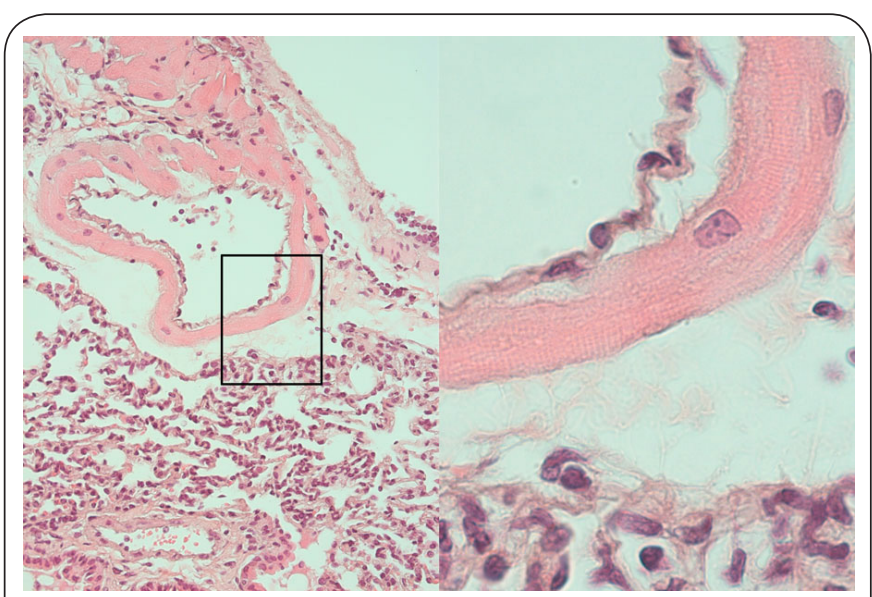

Figure 1. Pulmonary vein of mouse lung, H\&E-stained paraffin section. Left: magnification 400x, right: $1250 x$. Note a visible muscle striation in the right image.

However, no matter how familiar the finding is, it is always puzzling: Where do these striated muscles come from?

Currently, there is only one explanatory hypothesis of the origin of striated muscles in pulmonary veins. This model includes two non-excluding morphogeneses: 1 ) extension of sleeves of striated cardiac myocytes from the left atrium to the wall of pulmonary veins during embryogenesis [2]; and 2) migration of atrial myoblasts into pulmonary veins during atrial septation [3]. Therefore, the hypothesis assumes direct extension/migration of myocytes from the left atrium and unequivocally suggests the myocardial origin of striated muscles in pulmonary veins [4]. This model sounds logical in regard to large mammals (including humans) because in these cases striated myocytes extend to pulmonary veins only by $10-30 \mathrm{~mm}$ from the left atrium [5-9]. This striated muscle compartment of pulmonary veins in humans is the subject of special clinical attention because it is the source of ectopic beats initiating atrial fibrillation [10-13]. Similar myocardial striated sleeves extending near heart chambers into the beginnings of main vessels were found in the aorta, pulmonary artery [14,15], and caval veins [16].

However, the cardiomyocyte direct extension/migration model becomes less parsimonious when applied to numerous small intrapulmonary veins with striated muscles in their walls. Although the presence of striated muscle in smaller intrapulmonary veins inversely correlates with body mass (and positively with heart rate) [17], the appearance of striated muscles in distal segments of numerous intrapulmonary veins begs for a model other than direct cardiomyocyte extension/ migration from the left atrium. Striated myocytes were found in pulmonary veins with a diameter of 70-250 microns and even in pulmonary veins of 30 micronsin diameter in numerous species [18-23]. A quest for an alternative model also appears logical because cardiomyocyte extension/migration to distal pulmonary veins has been never demonstrated; the evidence has shown similarity in gene expression between striated muscle of pulmonary veins and heart myocytes $[3,4,24]$, which neither is a proof of cell migration nor the same developmental origin [25].

Therefore, the question is as follows: How can the presence of striated myocytes in small intrapulmonary veins, which are located very distal to the heart, be explained?

Recently, I realized that this quest was answered long ago.

I was studying (for an unrelated reason) the famous work of Alfred Sherwood Romer 'The Vertebrate as a Dual Animal Somatic and Visceral', when I came across the following notes on striated visceral muscle of mesenchyme origin:

"Histologically, vertebrate musculature can be divided into the striated type, which makes up the "flesh" of the body, and smooth musculature, with simpler fibers, which is mainly confined to the gut tube, although with "outliers" (particularly in higher vertebrates) in the vascular system and so forth (it is generally agreed that heart muscle is a derivative of the smooth muscle type). (p.122, [26]; and further:

"It seems clear that the pharyngeal group of muscles are a specialized part of a set of visceral muscles, associated with the gut, arising in a fashion similar to the smooth musculature found more posteriorly, but developing as striated fibers in connection with the functional need for more efficient musculature in the mouth and pharynx region." [26] (p.125).

The above notions carry two theoretical implications. Considering that the development of a striation phenotype in mesenchymal smooth muscle fibers is a reflection of functional needs and selection, it could be foreseen that:

1) this phenomenon could appear in the blood circulatory system in more than one place (i.e., heart); and 2) the striatedmuscle phenotype also could appear in visceral compartments other than the blood vascular system and the pharyngeal group of muscles if functional needs required it.

I decided to check whether there are available facts that support these theoretical implications, and the results of this simple inquiry stunned me.

\section{Implication \# 1}

This phenomenon could appear in the blood vascular system in more than one place (i.e., heart):

While I read 'The Vertebrate as a Dual Animal-Somatic and Visceral' long ago, only recently did I realize that the puzzling 
morphology of distal intrapulmonary veins constitutes the same phenomenon that Romer described as "the functional need for more efficient musculature" [26] because pulmonary veins rhythmically contract and propel blood to the left atrium $[3,18-20]$.

Within Romer's model, the puzzling and paradoxical striated muscle phenotype of distal pulmonary veins becomes explainable and expected.

Because the occurrence of the striated muscle phenotype in the heart is consequential to functional needs and selection, this logic is applicable to any blood-conducting compartment under similar demands. We do not have to infer a complicated model based on the myocardial origin of pulmonary striated muscles and cell migration along each developing intrapulmonary vein up to $30-50$ microns in diameter. There is a parsimonious model-visceral smooth muscle cells, which are capable of differentiating into striated muscle cells, are always present; whether they do differentiate into cardiac phenotype is just a matter of the functional demands. Therefore, the myocytes of intrapulmonary veins acquired the striation phenotype independently of heart myocytes due to the demand for "the functional need for more efficient musculature" [26].

In clinical pathology, the finding of striated muscle fibers in lung parenchyma, not in conjunction with vasculature, is not a rare observation [27-33]. It is usually attributed to trapping fragments of foregut tissues (i.e., pharyngeal muscles) into lung parenchyma before separation of the pulmonary bud from esophagus tissues in embryogenesis [28]. However, it was long ago suggested by R.A. Willis that striated muscles may develop from the lung mesenchyme itself as heteroplasia [34] (page 345). Sequestration of foregut cells into developing lung for striated muscle morphogenesis also seems unnecessary because many genes directing the striated muscle phenotype appeared activated in developing lung parenchyma [35]. It also was shown that visceral smooth muscle cells are able to develop the striated muscle phenotype well after commitment and differentiation [36], and cell migration is not necessary for the phenotype switch [37]. Furthermore, there is a known gene expression program that facilitates the spontaneous switch from a smooth to a skeletal muscle phenotype [38], and this switch can be bifunctional [39].

\section{Implication \#2}

Striated muscle could appear in visceral compartments other than the blood circulatory system and pharyngeal group of muscles to facilitate functional needs.

In vertebrates, a lymphatic system has to facilitate movement of lymph in one direction-from the periphery to the central venous system. Lymph propulsion is facilitated by voluntary muscle contraction, which surrounds conducting lymphatic vessels (mostly in the extremities), by the thrust of pulsing arteries (deep collecting lymphatics usually lying contiguous to the arteries in confines channels) [40] and by coordinated contraction of smooth muscle cells in lymphcollecting vessels [41]. Directional movement of the lymph is facilitated by lymphatic endothelial flaps, or valves, which prevent retrograde flow [42]; the contracting segment of a lymphatic vessel with two valves is known as a lymphangion [43].

What is less well known is that in addition to the above recognized mechanisms facilitating lymph movement, the lymphatic system of many vertebrates acquires a specific contractile organ named the lymphatic heart [44-57]. It was documented by many investigations that the main structural component of lymphatic hearts is striated muscle cells [e.g., $[45,46,48,50-52,54]$, with only one report on smooth muscle morphology of the lymphatic heart [49].

Apart from blood and lymphatic conducting systems, and visceral musculature in the mouth and pharynx regions, some vertebrates also acquire striated muscles in tunica Muscularis of the stomach $[\mathbf{5 8 , 5 9 ]}$ and intestine $[\mathbf{6 0}, \mathbf{6 1}]$.

The facts above undoubtedly corroborate Prof. Romer's hypothesis on the design of the vertebrate muscular system:

"Further evidence that the primary anatomical division of the vertebrate muscular system should be not into smooth and striated types but into somatic and visceral systems is afforded by the fact that the line of division along the gut between striated and smooth musculature is not a fixed point." [26] (p.125).

In addition to having great theoretical importance, the above statement on Romer's work highlights the feasibility of a very practical biomedical goal-the creation of an additional heart. The heart muscle is a derivative of the smooth muscle lineage, and differentiation of cardiac striated muscular compartments from smooth muscle cells or their progenitors is a physiologic event. Such organogenesis, as Prof. Romer noted, is the result of selection complying with "the functional need for more efficient musculature" [26]. Romer's insights together with the presence of myocardial compartments with autonomous contractility in visceral organs of vertebrates (pulmonary artery and lymphatic system) and recent scientific discoveries (e.g., [62-67]) should encourage funding of research aiming to construct of additional vascular compartments to propel blood in systemic circulation. The creation of "additional heart" is an enormous practical challenge but not a theoretical barrier.

\section{Competing interests}

The author declares that he has no competing interests.

\section{Acknowledgement}

This contribution to understanding the origin of striated muscles in visceral organs of vertebrates was influenced by numerous discussions with my father, my teacher in morphology and scientific mentor-Mikhail Ya. Subbotin, Professor of Histology and Embryology.

Publication history

EIC: Gaetano Giuseppe Magro, University of Catania, Italy. Received: 10-Aug-2016 Final Revised: 15-Sep-2016

Accepted: 23-Sep-2016 Published: 07-Oct-2016

\section{References}

1. Sato J, Doi T, Kanno T, Wako Y, Tsuchitani M and Narama I. Histopathology of incidental findings in cynomolgus monkeys ( macaca 
fascicularis ) used in toxicity studies. J Toxicol Pathol. 2012; 25:63-101. | Article | PubMed Abstract | PubMed FullText

2. Townsley MI. Structure and composition of pulmonary arteries, capillaries, and veins. Compr Physiol. 2012; 2:675-709. | Article | PubMed Abstract | PubMed FullText

3. Jones WK, Sanchez A and Robbins J. Murine pulmonary myocardium: developmental analysis of cardiac gene expression. Dev Dyn. 1994; 200:117-28. | Article | PubMed

4. Mommersteeg MT, Christoffels VM, Anderson RH and Moorman AF. Atrial fibrillation: a developmental point of view. Heart Rhythm. 2009; 6:1818-24. | Article | PubMed

5. Nathan $\mathrm{H}$ and Gloobe $\mathrm{H}$. Myocardial atrio-venous junctions and extensions (sleeves) over the pulmonary and caval veins. Anatomical observations in various mammals. Thorax. 1970; 25:317-24. | Article | PubMed Abstract | PubMed FullText

6. Saito $T$, Waki $K$ and Becker AE. Left atrial myocardial extension onto pulmonary veins in humans: anatomic observations relevant for atrial arrhythmias. J Cardiovasc Electrophysiol. 2000; 11:888-94. | Article | PubMed

7. Ho SY, Cabrera JA, Tran VH, Farre J, Anderson RH and Sanchez-Quintana D. Architecture of the pulmonary veins: relevance to radiofrequency ablation. Heart. 2001; 86:265-70. | Article | PubMed Abstract | PubMed FullText

8. Hassink RJ, Aretz HT, Ruskin J and Keane D. Morphology of atrial myocardium in human pulmonary veins: a postmortem analysis in patients with and without atrial fibrillation. J Am Coll Cardiol. 2003; 42:1108-14. | Article | PubMed

9. DeSimone CV, Noheria A, Lachman N, Edwards WD, Gami AS, Maleszewski JJ, Friedman PA, Munger TM, Hammill SC, Packer DL and Asirvatham SJ. Myocardium of the superior vena cava, coronary sinus, vein of Marshall, and the pulmonary vein ostia: gross anatomic studies in 620 hearts. J Cardiovasc Electrophysiol. 2012; 23:1304-9. | Article | PubMed

10. Oral H, Knight BP, Tada H, Ozaydin M, Chugh A, Hassan S, Scharf C, Lai SW, Greenstein R, Pelosi F, Jr., Strickberger SA and Morady F. Pulmonary vein isolation for paroxysmal and persistent atrial fibrillation. Circulation. 2002; 105:1077-81. | Article | PubMed

11. Pappone C, Rosanio S, Oreto G, Tocchi M, Gugliotta F, Vicedomini G, Salvati A, Dicandia C, Mazzone P, Santinelli V, Gulletta S and Chierchia $S$. Circumferential radiofrequency ablation of pulmonary vein ostia: $A$ new anatomic approach for curing atrial fibrillation. Circulation. 2000; 102:2619-28. | Article | PubMed

12. Chen SA, Hsieh MH, Tai CT, Tsai CF, Prakash VS, Yu WC, Hsu TL, Ding YA and Chang MS. Initiation of atrial fibrillation by ectopic beats originating from the pulmonary veins: electrophysiological characteristics, pharmacological responses, and effects of radiofrequency ablation. Circulation. 1999; 100:1879-86. | Article | PubMed

13. Haissaguerre M, Jais P, Shah DC, Takahashi A, Hocini M, Quiniou G, Garrigue S, Le Mouroux A, Le Metayer P and Clementy J. Spontaneous initiation of atrial fibrillation by ectopic beats originating in the pulmonary veins. N Engl J Med. 1998; 339:659-66. | Article | PubMed

14. Hasdemir C, Aktas S, Govsa F, Aktas EO, Kocak A, Bozkaya YT, Demirbas MI, Ulucan C, Ozdogan O, Kayikcioglu M, Can LH and Payzin S. Demonstration of ventricular myocardial extensions into the pulmonary artery and aorta beyond the ventriculo-arterial junction. Pacing Clin Electrophysiol. 2007; 30:534-9. | Article | PubMed

15. Lu J. Expression of protein-gene peptide (PGP) 9.5 in myocardial sleeves around the pulmonary artery and aorta in pigs. Scientific Research and Essays. 2012; 7:2992-2996. | Article

16. Steiner I, Hajkova P, Kvasnicka J and Kholova I. Myocardial sleeves of pulmonary veins and atrial fibrillation: a postmortem histopathological study of 100 subjects. Virchows Arch. 2006; 449:88-95. | Article | PubMed

17. Klika E, Zajicova A and Votavova B. [Participation of the myocardium in the formation of the pulmonary vein wall of small mammals (a quantitative study)]. Arkh Anat Gistol Embriol. 1982; 82:81-3. | PubMed
18. Millino C, Sarinella F, Tiveron C, Villa A, Sartore S and Ausoni S. Cardiac and smooth muscle cell contribution to the formation of the murine pulmonary veins. Dev Dyn. 2000; 218:414-25. | Article | PubMed

19. Paes de Almeida O, Bohm CM, de Paula Carvalho M and Paes de Carvalho $A$. The cardiac muscle in the pulmonary vein of the rat: a morphological and electrophysiological study. J Morphol. 1975; 145:409-33. | PubMed

20. Endo H, Mifune H, Maeda S, Kimura J, Yamada J, Rerkamnuaychoke W, Chungsamarnyart N, Ogawa K, Kurohmaru M, Hayashi Y and Nishida T. Cardiac-like musculature of the intrapulmonary venous wall of the longclawed shrew (Sorex unguiculatus), common tree shrew (Tupaia glis) and common marmoset (Callithrix jacchus). Anat Rec. 1997; 247:46-52. I PubMed

21. Mueller-Hoecker J, Beitinger F, Fernandez B, Bahlmann O, Assmann G, Troidl C, Dimomeletis I, Kaab S and Deindl E. Of rodents and humans: a light microscopic and ultrastructural study on cardiomyocytes in pulmonary veins. Int J Med Sci. 2008; 5:152-8. | Article | PubMed Abstract I PubMed FullText

22. Endo H. Cardiac Musculature of the Intrapulmonary Venous Wall as an Endocrine Organ of Atrial Natriuretic Polypeptide in Watase's Shrew (Crocidura watasei) and Musk Shrew (Suncus murinus). Journal of the Mammalogical Society of Japan. 1995; 20:109-115.

23. Endo H. Morphological Differences in the Musculature of the Pulmonary Venous Wall between Three Species of Caviomorph, the Nutria, Guinea Pig and Chinchilla. Journal of the Mammalogical Society of Japan. 1992; 17:111-118.

24. Anderson RH and Moorman AF. Recent developmental findings relevant to the clinical significance of the myocardial venous sleeves. $J$ Cardiovasc Electrophysiol. 2012; 23:1310-2. | Article | PubMed

25. Moorman AF and Anderson RH. Development of the pulmonary vein. Int J Cardiol. 2011; 147:182. | Article | PubMed

26. Romer A.S. The vertebrate as a dual animal-somatic and visceral. In Evolutionary biology (Dobzhansky, T.M., et al., ed.). 1972; 121-156.

27. Osmond R. An unusual congenital abnormality: striated muscle in the lung. Med J Aust. 1966; 1:296-7. | PubMed

28. Aterman K and Patel S. Striated muscle in the lung. Am J Anat. 1970; 128:341-58. | Article | PubMed

29. Chi JG and Shong YK. Diffuse striated muscle heteroplasia of the lung. An autopsy case. Arch Pathol Lab Med. 1982; 106:641-4. | PubMed

30. Chen MF, Onerheim R, Wang NS and Huttner I. Rhabdomyomatosis of newborn lung: a case report with immunohistochemical and electronmicroscopic characterization of striated muscle cells in the lung. Pediatr Pathol. 1991; 11:123-9. | PubMed

31. Hardisson D. Histogenesis of striated muscle cells in the newborn lung parenchyma (rhabdomyomatosis), lung morphogenesis and development. Pathol Res Pract. 1999; 195:725-6. | PubMed

32. Fraggetta F, Davenport M, Magro G, Cacciaguerra S and Nash R. Striated muscle cells in non-neoplastic lung tissue: a clinicopathologic study. Hum Pathol. 2000; 31:1477-81. | Article I PubMed

33. Hardisson $D$ and Nistal $M$. The origin of striated muscle cells in nonneoplastic lung tissue. Hum Pathol. 2001; 32:763-4. | Article | PubMed

34. Willis R.A. The borderland of embryology and pathology. Butterworth \& Co. 1962.

35. Warburton D, Zhao J, Berberich MA and Bernfield M. Molecular embryology of the lung: then, now, and in the future. Am J Physiol. 1999; 276:L697-704. | Article | PubMed

36. Rishniw M, Rodriguez P, Que J, Burke ZD, Tosh D, Chen H and Chen X. Molecular aspects of esophageal development. Ann N Y Acad Sci. 2011; 1232:309-15. | Article | PubMed Abstract | PubMed FullText

37. Rishniw M, Fisher PJ, Doran RM, Bliss SP and Kotlikoff MI. Striated myogenesis and peristalsis in the fetal murine esophagus occur without cell migration or interstitial cells of Cajal. Cells Tissues Organs. 2009; 189:410-9. | Article | PubMed Abstract | PubMed FullText

38. Graves DC and Yablonka-Reuveni Z. Vascular smooth muscle cells spontaneously adopt a skeletal muscle phenotype: a unique Myf5(-)/ MyoD(+) myogenic program. J Histochem Cytochem. 2000; 48:1173-93. | Article | PubMed 
39. Long X, Creemers EE, Wang DZ, Olson EN and Miano JM. Myocardin is a bifunctional switch for smooth versus skeletal muscle differentiation. Proc Natl Acad Sci U S A. 2007; 104:16570-5. | Article I PubMed Abstract I PubMed FullText

40. Kampmeier O.F. Evolution and comparative morphology of the lymphatic system. Thomas. 1969.

41. Wiig $\mathrm{H}$ and Swartz MA. Interstitial fluid and lymph formation and transport: physiological regulation and roles in inflammation and cancer. Physiol Rev. 2012; 92:1005-60. | Article I PubMed

42. Schmid-Schonbein GW. Microlymphatics and lymph flow. Physiol Rev. 1990; 70:987-1028. | Article I PubMed

43. Margaris KN and Black RA. Modelling the lymphatic system: challenges and opportunities. J R Soc Interface. 2012; 9:601-12. I Article | PubMed Abstract I PubMed FullText

44. Krylova MI and Bogolyubov DS. An early post-traumatic reaction of lymph-heart striated muscle fibers in adult frog Rana temporaria during the first postoperative week: An electron microscopic and autoradiographic study. J Morphol. 2015; 276:1525-34. | Article | PubMed

45. Zhang R, Taucer AI, Gashev AA, Muthuchamy M, Zawieja DC and Davis MJ. Maximum shortening velocity of lymphatic muscle approaches that of striated muscle. Am J Physiol Heart Circ Physiol. 2013; 305:H1494-507. | Article | PubMed Abstract | PubMed FullText

46. Muthuchamy M, Gashev A, Boswell N, Dawson N and Zawieja D. Molecular and functional analyses of the contractile apparatus in lymphatic muscle. FASEB J. 2003; 17:920-2. | Article | PubMed

47. Crossley DA, 2nd and Hillman SS. The role of pulmocutaneous baroreceptors in the control of lymphatic heart rate in the toad Bufo marinus. Physiol Biochem Zool. 1999; 72:109-15. | Article I PubMed

48. Vogel $W$ and Mattheus, U. Lymphatic vessels in lungfishes (Dipnoi). Zoomorphology. 1998; 117:199-212. I Article

49. Liu ZY and Casley-Smith JR. The fine structure of the amphibian lymph heart. Lymphology. 1989; 22:25-30. I PubMed

50. Markozashvili MI and Rumyantsev PP. Ultrastructure of muscle fibers and cells synthesizing DNA in lymph hearts of developing frogs and chick embryos. Cell Tissue Res. 1984; 238:369-79. I PubMed

51. Berens von Rautenfeld D and Budras KD. TEM and SEM investigations of lymph hearts in birds. Lymphology. 1981; 14:186-90. I PubMed

52. Davie P.S. Neuroanatomy and control of the caudal lymphatic heart of the short-finned eel (Anguilla australis schmidtii). Canadian Journal of Zoology. 1981; 59:1586-1592. I Article

53. Kampmeier O.F. The development of the trunk and tail lymphatics and posterior lymph hearts in anuran embryos. J Morphol. 1925; 41:95-157.

54. Sabin F.R. The origin and development of the lymphatic system. Johns Hopkins Hospital Reports. Monographs, new series. 1913.

55. Sabin F.R. On the origin of the abdominal lymphatics in mammals from the vena cava and the renal veins. Anat Rec. 1912; 6:235-242. I Article

56. Sabin F.R. On the origin of the lymphatic system from the veins and the development of the lymph hearts and thoracic duct in the pig. American Journal of Anatomy. 1902; 1:367-389. I Article

57. Jones T.W. The Caudal Heart of the Eel a Lymphatic Heart. Effect of the Force with Which the Lymph-Stream is Propelled Therefrom on the Flow of the Blood in the Vein into Which the Heart Opens. Explanation of the Appearance of Blood Propelled in Successive Drops, as If from the Heart, along the Caudal Vein. Influence Which the Force of the Lymph-Stream from the Heart Exerts in Accelerating and Promoting the Flow of Blood in the Caudal Vein. Philosophical Transactions of the Royal Society of London. 1868; 158:675-683. I Article

58. Osman A and Caceci T. Histology of the stomach of Tilapia nilotica (Linnaeus, 1758) from the River Nile. Journal of Fish Biology. 1991; 38:211-223. I Article

59. Caceci T. The stomach of Oreochromis niloticus has three regions. Journal of Fish Biology. 1997; 50:939-952. | Article

60. Kilarski W and Bigaj J. The fine structure of striated muscle fibres of tunica muscularis of the intestine in some teleosts. Z Zellforsch Mikrosk
Anat. 1971; 113:472-89. I PubMed

61. Comabella Y. Ontogenetic development of the digestive tract in Cuban gar (Atractosteus tristoechus) larvae. Reviews in Fish Biology and Fisheries. 2013; 23:245-260. | Article

62. Vunjak-Novakovic G, Lui KO, Tandon N and Chien KR. Bioengineering heart muscle: a paradigm for regenerative medicine. Annu Rev Biomed Eng. 2011; 13:245-67. | Article | PubMed Abstract | PubMed FullText

63. Kelly R.G. THE SECOND HEART FIELD. In Heart Development (Vol. 100) (Bruneau, B.G., ed.). 2012; 33-65. I Article

64. Buckingham M. Tissue Differentiation: A Personal Account of Research on Myogenesis and Cardiogenesis. Curr Top Dev Biol. 2016; 116:135-51. | Article | PubMed

65. Watanabe Y, Miyagawa-Tomita S, Vincent SD, Kelly RG, Moon AM and Buckingham ME. Role of mesodermal FGF8 and FGF10 overlaps in the development of the arterial pole of the heart and pharyngeal arch arteries. Circ Res. 2010; 106:495-503. | Article | PubMed Abstract | PubMed FullText

66. Vincent SD and Buckingham ME. How to make a heart: the origin and regulation of cardiac progenitor cells. Curr Top Dev Biol. 2010; 90:1-41. | Article I PubMed

67. Mommersteeg MT, Brown NA, Prall OW, de Gier-de Vries C, Harvey RP, Moorman AF and Christoffels VM. Pitx2c and Nkx2-5 are required for the formation and identity of the pulmonary myocardium. Circ Res. 2007; 101:902-9. I Article | PubMed

\section{Citation:}

Subbotin VM. Striated muscles in visceral organs of vertebrates. J Histol Histopathol. 2016; 3:3. http://dx.doi.org/10.7243/2055-091X-3-3 